\title{
The Mazama returns: the politics and possibilities of tribal land reacquisition
}

\author{
Erin Clover Kelly ${ }^{1}$ \\ John C. Bliss \\ Hannah Gosnell \\ Humboldt State University, USA \\ Oregon State University, USA
}

\begin{abstract}
The goals of the Klamath people are simple and reflective of those to which most communities
\end{abstract} aspire. The Klamath people wish to be self-sufficient. (Klamath Tribes 2012) ${ }^{2}$

\section{Introduction}

Across the globe, indigenous peoples have been displaced from their homelands, with attendant loss of cultural cohesion, economic well-being, and political sovereignty. But since the 1970s, indigenous groups have forged gains in political power and capacity, including expanded access to former treaty or ceded lands, and in some cases, reacquisition of those lands. While the rising power of indigenous people in North America has been documented (e.g. Wilkinson 2005), few studies have focused on the re-acquisition of former tribal lands, though from 1998 to 2007, about 340,000 ha were put into Federal trust, adding to the 22.3 million ha already in trust (Ross 2009). This case presents the context and the mechanisms that have allowed one group, the Klamath Tribes ${ }^{3}$, to position itself to purchase the Mazama Tree Farm (Mazama), 36,000 ha of former reservation lands, and queries the connections among politics, economics, power, and social-ecological change in Indian country. In this case study, we explore the relationships between Indian land rights and capacity, in light of the view that regaining land may be a significant step to tribal autonomy and self-determination (Zaferatos 2004).

We also highlight the context for reacquisition, including rural restructuring and land availability, and identify broader enabling principles that could be relevant elsewhere. In order to better understand the context of reacquisition, we utilize a political ecology approach, linking processes of power and decisionmaking access with land rights. Political ecology is a broad academic arena which links environmental change with "political choices, institutional structures, and power relations that cannot be separated from the broader political-economic dynamics of globalization" (McCarthy 2004: 327). Land and natural resource use are therefore examined within multi-scalar political and cultural systems (Robbins 2004). Power here refers to the ability of different actors to influence political and economic outcomes, not only to identify problems and propose solutions, but to set the "rules of the game" and influence the institutional and structural processes that determine who is allowed to participate, and the way decisions are to be made (Takeda and Ropke 2010). Power is also recognized as contested and tenuous, as dominant groups seek to reassert their claims (Braun 2002). This research builds upon the themes of political ecology in the western United States, where rationalized natural resource management has integrated rural economies into global market systems (Prudham 2005), differing social constructions of the landscape have led to conflicts regarding the appropriate relationships between humans and nature (Walker and Fortmann 2003; McCarthy 2002), and American Indian groups have struggled to reclaim decision-making authority over traditional lands (Ishiyama 2003). Similar themes have emerged in Australia and Canada, particularly as Aboriginal groups gained control over traditional lands through either ownership or co-management (Dempsey 2010; Holmes 2010; Takeda and Ropke 2010; Wyatt 2008).

\footnotetext{
${ }^{1}$ Dr Erin Kelly, Assistant Professor, Dept. of Forestry and Wildland Resources, Humboldt State University, 1 Harpst Street, Arcata, CA 95521, USA. Email: eck107 "at" humboldt.edu. Prof. John Bliss, Department of Forest Ecosystems and Society, Oregon State University, Corvallis, Oregon, 97331, USA. Dr Hannah Gosnell, Associate Professor, College of Earth, Ocean, and Atmospheric Sciences, Oregon State University, USA. We acknowledge funding provided by the Shutz Family Fellowship and Dorothy D. Hoener Scholarship at Oregon State University, and the Rural Initiative of Oregon State University. Thankyou to all the participants in the study, and especially the Klamath Tribes.

${ }^{2}$ From the Klamath Tribe webpage: http://www.klamathtribes.org/background/termination.html, accessed June 26, 2012.

${ }^{3}$ The Klamath Tribes are often referred to as the Klamath Tribe; however the more modern usage is the Klamath Tribes as they consist of three tribes, the Klamath, Modoc, and Yahooskin Band of the Snake.
} 
This case offers an example of tribal reacquisition of land through private timberland purchase, a type of opportunity that is growing as rural areas in the U.S. undergo economic and social restructuring. Land disinvestment has occurred prominently on formerly industrially-owned forests as new landowners seek returns from multiple sources, including land sales to non-traditional ownerships (Bliss et al. 2010). Tribes may benefit particularly from this breakup of the industrial forest tenure, as they have a commitment to purchase lands grounded in legal, moral, economic, cultural, and identity-based claims (Hibbard and Lane 2004). This is occurring in the context of expanding federal and non-governmental organization funding and support for tribal land reacquisition, and a growing tribal capacity to purchase and manage land. Particularly in the case of degraded forests, and in regions with disappearing forest industry infrastructure, tribes have an unprecedented opportunity to purchase their historical lands.

One challenge of the current movement toward tribal ownership is in linking tribal stewardship and ecological knowledge with modern socio-economic circumstances and management based on ecological resilience and restoration (e.g. Puettman et al. 2008). As such, any consideration of the potential for tribal reacquisition of former industrial forest land must take into account the ecological impacts of years of industrial forest management and tribal willingness and capacity to engage in forest restoration.

Through our research we asked: What are the drivers and consequences of rising tribal power, including social, economic, and political factors at local and national (U.S.) scales? What are the links between tribal capacity and tribal land reacquisition? What is the role of forest land in a changing rural economic and social context, particularly with the historical overlay of tribal treaties?

In the following sections we first review literature on tribal land re-acquisition, connections between power and land, and rural restructuring. This is followed by a review of the Mazama case; we then return in the discussion to the themes of tribal capacity and land rights and restoration.

\section{Tribal land reacquisition}

American Indian tribes have a long history of physical and livelihood displacement and loss of ancestral homelands. Federal policies such as the Indian Removal Act of 1830 and the General Allotment Act of 1887 resulted in the loss of 37 million ha $(91 \mathrm{~m}$ acres) from tribal ownership, almost two-thirds of tribal treaty lands (25 USC 2201 \$101). These policies and others, along with U.S. government fraud, treaty abrogation, and other land grabs resulted in enclosure and privatization of formerly tribal lands, with Indians often excluded (Wilkins 1987).

But this has changed since at least the Indian Self-Determination and Education Assistance Act of 1975, which transferred management authority from governmental agencies such as the Bureau of Indian Affairs to tribes (Middleton and Kusel 2007), forming the "era of self-determination" (Rasmussen et al. 2007). Self-determination has been linked with land reacquisition, in part a response to tribal sovereignty struggles focused on "how to maintain or regain control over resources, especially land" (Hibbard, 2006: 88). Tribal land claims were extended and clarified as a result of political and legal decisions, such as the Indian Land Consolidation Act of 1983, which addressed the fractionalization of Indian lands as ownership passed through inheritance to large number of heirs, in order to "enhance tribal sovereignty ... and reverse the effects of the allotment policy" (25 USC 2201 \$102). Other federal policies provided loans for tribal land reacquisition, such as the 2001 Indian Tribal Land Acquisition Program, while the 2004 Tribal Forest Protection Act extended tribal access to neighboring national forests by facilitating tribal-U.S. Forest Service land management partnerships.

Funding for land reacquisition also flowed in the 1990s from federal agencies such as the Bonneville Power Administration, which had dammed the Columbia and Snake rivers in the Pacific Northwest, decimating salmon runs. In the 1990s, the Confederated Tribes of the Umatilla Indian Reservation received mitigation funds from the BPA to purchase two parcels along the Columbia River totaling 1000 ha, and the Wallowa Band of the Nez Perce received funds to purchase 4000 ha. Funding is also available to individual tribal members as a result of Cobell v. Salazar, a class action lawsuit that will address chronic federal mismanagement of tribal resources.

Reacquisition has been facilitated through partnerships with non-profit organizations such as the Native American Land Conservancy, established in 1998, and the nationwide Indian Land Tenure Foundation, established in 2001, which provide grants for small-scale land acquisition and protection projects. The most formidable non-profit organization in Indian land reacquisition is the Trust for Public Land (TPL) Tribal and Native Lands Program, established in 1999, which has negotiated purchases or conservation easements on 81,000 ha across the U.S. (Blair 2010). Indian land that has been purchased can then follow two paths. First, the land can remain held in fee simple, in which it is taxed and regulated in common with other private lands. This arrangement can be antithetical to the efforts of tribes for selfdetermination and to the government-to-government status of tribes. Second, the land can be transferred into trust land, which is held by the U.S. government while the tribes retain rights of use. The trust relationship is grounded in the recognition of tribal rights and mandates that the U.S. government manage the land for the benefit of tribes. 
Finally, capacity-building efforts within Indian tribes have enabled them to spearhead acquisition efforts. Individual tribes have established land purchase programs, including the Yakama Nation, which purchased 11,300 ha in 2001 from International Paper - an industrial forest company divesting its timberlands (Harvard Project 2002).

\section{Power and land}

Land provides the setting for power struggles and negotiations, from national political struggles to local and regional land use conflicts. Laws, policies, and power interact on the landscape, weaving a social and cultural history that is transcribed upon it through human actions. The American West has been the setting of a number of seemingly intractable natural resource conflicts surrounding land and natural resource use (Wilkinson 1992) and Indian tribes have been involved in many of these conflicts as landowners, litigants, or protesters (Ishiyama 2003; Zaferatos 2006). Indian treaty lands are particularly imbued with a contentious history, as tribal members have been forcibly moved to and away from these spaces and their land management decisions have been shaped by distant policy makers.

As Indian lands were taken or reshaped, the power of tribes diminished. The 1887 Allotment (Dawes) Act, mentioned above, was reminiscent of the Homestead Act in its attempt to create a landscape of smallscale agrarian farmers, but its effect was to break apart Indian lands, and thus break up Indian tribes. In the words of the Commissioner of Indian Affairs:

It has become the settled policy of the Government to break up reservations, destroy tribal relations, settle Indians upon their own homesteads, incorporate them into national life, and deal with them not as nations or tribes or bands, but as individual citizens. (Morgan 1890: 690)

In contrast, the growing control over traditional lands has reaffirmed tribal self-determination, cultural vitality, and economic well-being (Wilkinson 2005). This extends also to the power to make land use management decisions, and to gain access to political processes centered on natural resource use (Castree 2004).

\section{Rural restructuring}

Tribal land reacquisition is occurring within the context of changing rural land use, policies, and tenures, as timber and ranch land owners divest ownership, resulting in greater land availability. In the case of forests, tens of millions of hectares of privately-owned, formerly industrial timberland have been put up for sale in the U.S. since the 1990s, as industrial forest companies have disaggregated their timberlands and sold them to non-industrial investors, real estate developers, and land trusts (Bliss et al. 2010). Tribes are another potential beneficiary of the dissolving industrial forest estate.

Along with the decline of industrial forest ownership, across the U.S., many rural places have lost capacity in commodity production, typified by the deterioration of regional timber and agricultural markets (Winkler et al. 2007) and economic and cultural shifts from commodity production to a focus on amenities, recreation, and real estate development (Albrecht 2004; Gosnell and Abrams 2011). Management priorities on many 'working' lands have changed from maximum commodity utilization to multiple objectives, including restoration (Wilson 2007; Mather 2001) opening up land management opportunities for new actors, including tribes (Memon and Wilson 2007; Rasmussen et al. 2007).

\section{Methods}

Research was conducted between 2007 and 2009 and relied primarily on interviews ( $\mathrm{n}=22$ ). Interviewees were chosen purposively based on their connection with the Mazama, their connection to the forest industry in Klamath County, or their participation in the Klamath Basin Restoration Agreement (KBRA). Interviewees included tribal members, politicians, forest and sawmill managers, non-profit employees, and irrigators. All interviews were recorded, transcribed, and coded for their relevance to research questions. We analyzed historical and current documents related to the history of the Klamath Tribes and their reservation, including U.S. Forest Service documentation regarding forest management on the Mazama. ${ }^{4}$

\footnotetext{
${ }^{4}$ All Mazama documentation is located at the USFS Lakeview Ranger District in Lakeview, Oregon.
} 
We focused on the Klamath Tribes' reacquisition of the Mazama because of its value as a case study for understanding:

1) changing power relations among tribal and non-tribal groups, and

2) rural restructuring in the American West.

The Klamath Reservation existed in the Upper Klamath Basin in present-day Klamath County in south central Oregon from the signing of their 1864 treaty until termination in 1954 (Figure 1). As described more fully below, following termination their land base was dissolved and the Tribes fell from relative economic prosperity to dire poverty. Since at least 1986, when tribal recognition was restored, the Klamath Tribes have fought to regain control over their former reservation. In 2008, the Klamath Tribes announced the likely reacquisition of the Mazama.
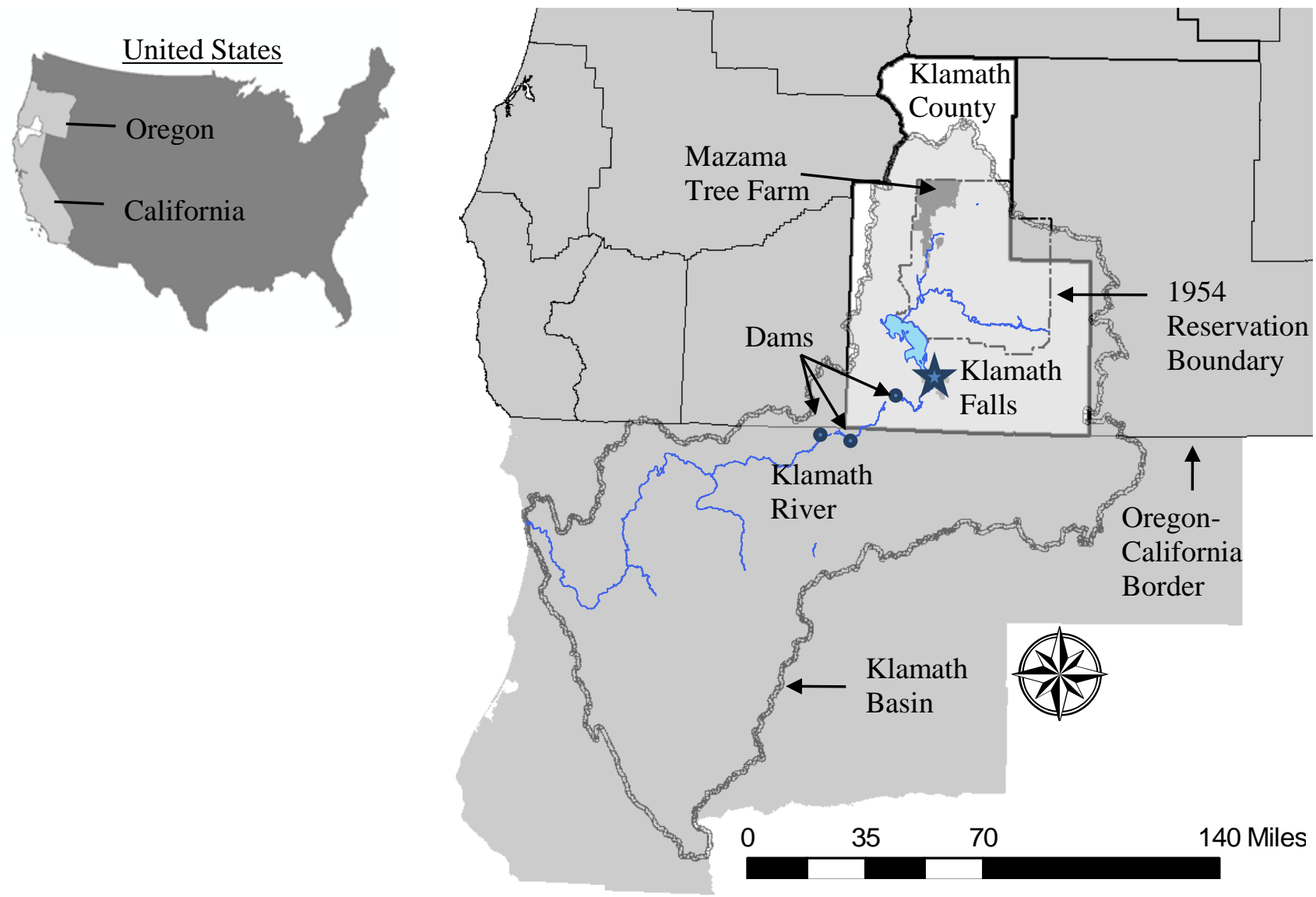

Figure 1: Map of the Klamath Basin showing the former Klamath Reservation with its 1954 boundaries, Klamath County, and the Mazama. Inset is a map indicating the location of the Klamath Basin within the U.S. Reservation boundary data was provided by Klamath Tribes.

As of June 2012, the Klamath Tribes do not own the Mazama. However, the potential for reacquisition of such a large section of historically tribal land illustrates changes occurring across the rural U.S., including its shifting power structures, transitions in forest management from long-term overharvesting to restoration and rehabilitation, and negotiations over long-standing conflicts regarding land and water use. We outline some of this history for the former Klamath Reservation and the surrounding Klamath Basin below. 


\section{History of the Klamath Tribes: displacement and termination}

The history of the Klamath Tribes is characterized by displacement and Euro-American accumulation of land through dispossession (Harvey 2007). As settlers and their institutions entered the Klamath Basin, an existent society with economic, ecological, and social systems collapsed. In a process repeated across the world, rationalized management schemes, including scientific forestry, replaced indigenous tenure and management systems (Bryant 1998). The Klamath Tribes, initially three tribes, the Klamath, Modoc, and Yahooskin band of the Snake (Paiute), were bound to the Klamath Reservation by the Treaty of 1864; in signing the treaty, the Tribes forfeited over 8 million ha of their homelands for a reservation of 810,000 ha.

The Reservation was fragmented in the years following its creation, and tribal capacity diminished concurrently. The 1887 Allotment Act divided commonly-held land into individual, privately-owned 65-ha parcels. Approximately $25 \%$ of the Klamath Reservation was allotted to individual members, and about half these lands were then sold to non-Indians; unallotted lands, often timbered, remained common resources (Tonsfeldt 1980). In addition, federal surveys in 1871 and 1888 excluded over 240,000 ha from the reservation, and in 1906, 35,000 ha were carved from the reservation and sold to industrial forest interests (Doremus and Tarlock 2008).

In the 1940s and 50s, federal legislators established policies to terminate recognition of Indian tribes, intending to end federal supervision and assimilate Indians into mainstream culture (Getches et al. 2005). The Klamath Tribes were among the first tribes to be recommended for termination because of their financial and material success, based on their reservation timber resources (Hood 1972). In 1954, the Klamath Tribes were terminated, severing ownership of their remaining 360,000 ha reservation (Klamath Tribes 2012a).

Motivations behind termination were complex; indeed, the Tribes themselves were highly factionalized, and several opposing viewpoints claimed to represent the 'Indian' perspective (Stern 1961). While the Klamath Tribes were ostensibly terminated for their benefit, they did not vote on termination; rather, tribal members were given the option of either withdrawing from the tribe in exchange for a cash payment, or becoming 'remaining members', who would have a collective interest in a privately-administered parcel of land. In the vote, 1,659 members withdrew, 80 remained, and 393 did not vote but were assigned to the remaining group.

Prior to termination, about $65 \%$ of tribal members were economically dependent on per-capita timber income payments, which put tribal incomes on par with non-tribal Klamath County residents (Hood 1972; Trulove and Bunting 1971). While tribal members received timber payments, few were employed in the forest industry and forest management was controlled by the Bureau of Indian Affairs. Many tribal members resented that their knowledge about forest management was discounted, as was the case with fire management, as described in an interview with a Tribal council member:

When the European comes and cleans these canopies and all this undergrowth is growing, and the tribes are trying to burn, they say wait a minute, what are you doing? Fire is bad. They're coming to the tribes now, hey, we need to talk about fuels reduction. We're never consulted on anything. (Tribal member, 2008 interview)

Though tribal members had little input into forest management, termination dissolved the Tribes' greatest remaining asset, their land base, and ended federal entitlement programs and agency support (Stern 1965; Trulove and Bunting 1971). When withdrawing members received US\$43,000 each in 1961, many tribal members were taken advantage of by shopkeepers, bankers, lawyers, and each other; as of $1965,80 \%$ of withdrawing members had less than half their money left, and $40 \%$ had nothing left (Trulove and Bunting 1971). Tribal well-being was decimated with the loss of the land and termination policies failed to integrate tribal members successfully into dominant Euro-American culture. From 1966 to 1980, poverty levels rose to three times that of non-Indians in Klamath County (Klamath Tribes 2012a).

\section{The forest industry and reallocation of tribal resources following termination}

Federal congressional hearings regarding the Tribes' termination were primarily concerned with the reallocation of tribal resources, especially timber (Hood 1972). At the time of termination, the timber industry represented $40 \%$ of the Basin's economic activity, and the Klamath Reservation contained $24 \%$ of its remaining timber (Wilcox 1956). About 4.6 billion board-feet (10.6 billion litres) of timber had been harvested from the Reservation, and 4.2 billion board-feet (9.2 billion litres) remained (Neuberger 1959). Forests of the Klamath Basin were mostly dominated by large ponderosa pine, with landscape-level heterogeneity maintained by frequent fires (Oliver et al. 1994) while lodgepole pine, long considered an economically non-valuable species, occurred as a subordinate species within ponderosa pine stands (Youngblood et al. 2004), or as pure stands in topographic depressions (ODF 2009a).

In the early $1950 \mathrm{~s}$, the regional industry was undergoing contraction and mill closure and the sale of reservation timberland would have resulted in a surge of timber supply and an accompanying boom in sawmill infrastructure (Wright 1956). Vested industrial forest companies had reason to fear an influx of new 
sawmills, and U.S. Senator Neuberger of Oregon responded to the concerns of Klamath Falls sawmill owner L.L. Shaw that "surely no one wants to see a boom community followed by the blight that would settle over the entire community once the timber resources were gone" (Neuberger 1955: 1).

Because of these concerns over (Euro-American) community and industry stability, the U.S. government offered the timbered pieces of the Reservation in large ( $>2000 \mathrm{ha}$ ) blocks to industrial forest operators, with sustained-yield management requirements, defined as a forest "capable of continuously producing [timber]" (USFS 1959: 2) attached to each timber unit, in the belief that large operators would maintain long-term operations with steady output (Neuberger 1959). Prospective owners were required to create 10-year management plans and inventories, which were monitored by the U.S. Forest Service - a unique requirement for private land. But the Mazama was the only unit that sold to an industrial forest company; the remainder of the forested land on the former reservation was purchased by the U.S. government and incorporated into the national forest system.

The Mazama, which had lost 75-80\% of its volume in harvests during the 1930s, had a large supply of small-diameter lodgepole suitable only for pulpwood, and limited ponderosa or lodgepole pine sawtimber (USFS 1959). Other units offered for sale had more valuable timber resources, but companies may have balked at the high prices when ponderosa pine was still available on public lands.

\section{Forestry on the industrial Mazama}

The Mazama was initially purchased by Crown Zellerbach, a company sold in 1986 and renamed Cavenham Forest Industries; then sold to Hanson Natural Resources in 1991. It was purchased by Crown Pacific in 1996, which held it until its bankruptcy in 2004. In 2006, one of Crown Pacific's creditors, Fidelity National Financial (Fidelity), gained control of the Mazama. Mandatory 10-year management plans and inventories and yearly USFS inspections resulted in a large amount of collected data of forest management and conditions on the Mazama, and revealed that despite sustained yield requirements, immediate economic considerations drove silvicultural practices, resulting in forest degradation.

The Mazama was to be managed to "improve the health and growing capacity of both ponderosa and lodgepole stands" (Crown Zellerbach 1980: 6). However, merchantable ponderosa pine was disproportionately targeted for harvest; over a third of the large ponderosa was cut in the first 10-year cutting cycle (Semmens 1976). Remnant ponderosa stands were replaced by lodgepole pine stands, because many ponderosa stands had an understory of lodgepole, and ponderosa reforestation was a continual problem. In 1970, at least a third of ponderosa stands were "bare or poorly stocked" (Crown Zellerbach 1970) and by 1980 , overstory removal had resulted in the conversion of 3,600 ha from ponderosa to lodgepole (Crown Zellerbach 1980).

Every ten-year plan stated that lodgepole pine harvests would increase as markets became available, but these markets never materialized. Lodgepole is a relatively short-lived, disease- and wildfire-prone species which proliferates in dense thickets in the absence of fire. By 1980, "the silvicultural objective [was] to convert the whole lodgepole type toward a healthier forest of younger even-aged stands, with better spacing of individual trees as a stimulus to better growth" (Crown Zellerbach 1980: 11), although this never occurred.

In addition, the plans did not adapt to changing political or economic circumstances. Management plans were intended to be adaptable and "neither more nor less stringent than the management now and subsequently imposed on comparable national-forest lands" (USFS 1959: 1). Neighboring national forest lands, similar to the Mazama, had been substantially homogenized, resulting in dense stands at risk of historically atypical stand-replacing wildfire (Johnson et al. 2008). In response, national forest management changed dramatically in the 1990s, shifting toward ecosystem management and restoration. However, management of the Mazama was maintained much as it had been practiced since 1961 (USFS employee, 2008 interview).

Management of the Mazama was initially established to support a timber-based economy; but revisions were allowed for "radical shifts in the basic economy" (USFS 1959: 10). These radical shifts occurred in Klamath County as forest employment fell by $70 \%$ from 1976 to 2008 (Oregon Employment Department 2009) and harvest levels declined by 89\%, from a high of over 600 million BF in 1971 to 67 million BF in 2008 (ODF 2009b). Mill closures began in the late 1970s and continued through the 2000s (Herald and News 2009), and alongside these closures was a loss of associated human capital, described by a Klamath County Commissioner as a "severe loss of a skill set" (Klamath Co. Commissioner, 2008 interview).

Though its management plans were designed to be flexible and adaptive, status-quo industrial management planning on the Mazama persisted despite evidence of changed socioeconomic circumstances and resource degradation.

\section{The Klamath Basin context: conflicts over land and water}

Tribal history in the Klamath Basin is situated within the context of federally sponsored farming projects that enabled Euro-American settlement and set the stage for ecological and economic transformation 
of the Basin. For most of the $20^{\text {th }}$ century, water management in the Klamath River was dictated by EuroAmerican irrigation needs and downstream river flows for several hydroelectric dams (Marbut 2002). This arrangement was interrupted by the convergence of legal, political, and ecological circumstances, described briefly below and more extensively elsewhere (Braunworth et al. 2002; Doremus and Tarlock 2008).

In 1975, the state of Oregon began adjudicating water claims on the Klamath River, assigning quantified water rights to claimants based on a priority date. The Klamath River had over 700 water claims, including 393 from the Klamath Tribes (Doremus and Tarlock 2008). Tribal water claims were nonconsumptive - meant for habitat provision for fish species - which conflicted with the water needs of both agricultural irrigators and dams. A series of lawsuits clarified that the Klamath Tribes had the oldest water rights in the basin ${ }^{5}$, and that treaty species and their habitats were protected because the Tribes had retained hunting and fishing rights on their former Reservation (Doremus and Tarlock 2008).

In 1988, two treaty fish species, the Short-nosed sucker (Chasmistes brevirostris) and Lost River sucker (Deltistes luxatus), were listed as endangered under the Endangered Species Act (ESA). The suckers' primary habitat was the Upper Klamath Lake and its reservoirs, the same waters that were used to control flow to irrigators (McHenry 2003). In 2001, federal wildlife agencies recommended changing Basin water allocations and a U.S. District Court halted irrigation flows, resulting in losses of between US\$37.5 and \$54 million in gross crop revenues (Jaeger 2002).

With the water shut off, reactions from irrigators and their supporters were swift and impassioned. In Klamath Falls, thousands participated in a symbolic bucket brigade in May 2001, and in August a 'Convoy of Tears' rolled through town, with a traveling 10-foot bucket from Elko, Nevada that was installed in front of the Klamath Government Center. Irrigator activists illegally breached the closed headgates; one protester told a reporter that "it felt like freedom ... It was standing against what was morally wrong" (quoted in Hecht 2001). The battle over Klamath Basin water was thus framed as a battle between Indian tribes and irrigators.

\section{Leveraging conflict: land re-acquisition proposals and tribal restoration}

Though the Indian Self-Determination Act ended the failed termination policies in 1975 and Klamath Tribal status was restored in 1986, no land was returned to the Tribes. While the Tribes retained access to some lands through their hunting and fishing rights, they sought to regain ownership of their former lands, as expressed in their constitution:

It shall be the policy of the Klamath Tribes to seek the return... of all lands, natural and cultural resources... that become available and which were historically a part of the Klamath Tribes heritage. (Klamath Tribes 2000:4)

In the midst of the Klamath Basin water conflicts, the Klamath Tribes put together concrete plans for "the return of the Tribes' land base as an essential element of their restoration as a people" (Klamath Tribes, 2012b, webpage). From 2002, the Klamath Tribes pressed for the return of 280,000 ha (692,000 acres) of national forest lands that were former reservation lands. The Tribes contracted three prominent non-tribal forest scientists to write a forest management plan (the 'Johnson Plan'), which argued for extensive restoration, including re-introduction of fire as a disturbance agent (Johnson et al. 2008). The plan was intended to give the Tribes control over their former reservation lands, in part by assuring the U.S. government that the Tribes would manage their forest resources in line with the most recent scientific principles: "If you're going make an ask like that [for the national forest lands], then you'd better have a plan to show people that you've got a plan on how to manage it" (Klamath forester and tribal member, 2008 interview). The Johnson Plan was based on ecosystem management and the need to manage for historical variability. Primary management goals of the plan emphasized restoring a heterogeneous forest structure and resilience to disturbances, especially fire and bark beetles. In lodgepole forests, the Johnson Plan called for: "much lower densities and... stand mosaics of different ages and densities, rather than extensive areas of dense, contiguous forests" (Johnson et al. 2008: 6). Specific prescriptions included pre-commercial thinning and rejuvenation of bitterbrush understory for mule deer. This multi-objective approach differs notably from industrial ownership, where "they go in, they harvest about 10 million board feet a year, they do absolutely nothing else... ours would be more intense management, with the idea of improving forest health" (Klamath forester and tribal member, 2008 interview).

The proposals for tribal takeover of the national forest lands were met with strong opposition from irrigators. The chairman of the Klamath Basin Alliance, a group of irrigators, wrote:

\footnotetext{
${ }^{5}$ Three additional tribes, the Karuk, Yurok, and Hupa, were also pivotal in the water and land use conflict in the Klamath Basin, and in the creation of the KBRA.
} 
As American citizens we have a moral obligation to preserve our national forests for future generations ... But there is a bigger question of the great injustice of Tribal sovereignty where the tribes have used the endless checkbook of the federal government, attacking our agricultural community. (Bayona 2002)

This quote, and numerous similar to it, provide evidence for the perceived shifts in power between Indian tribes and irrigators. Changes in federal government policies shifted from supporting irrigator livelihoods in spite of tribal treaty rights toward (tentatively) supporting tribal land claims in the face of irrigator protests. This suggests a fundamental change in the power arrangements in the Basin.

\section{Possible resolution: the KBRA}

This attempt to reacquire national forest lands did not succeed. But within the changing power structure of the Basin, the Klamath Tribes positioned themselves to reacquire a different piece: the Mazama. This was facilitated through two converging conditions:

1) negotiations over the persistent water and land use conflicts wherein the Tribes were able to leverage water rights for land; and

2) availability of the Mazama on the market, because of ownership change, degraded timber conditions, and the declining profile of the timber industry in the region.

The 2001 water shutoff initially aggravated long-standing animosity between tribes and irrigators, but was eventually followed by a series of collaborative negotiations that led to a multi-faceted agreement, the Klamath Basin Restoration Agreement (KBRA) among the Klamath Tribes, three other downstream tribes, irrigators, governmental agencies, and non-governmental organizations. The KBRA aimed to create an overarching agreement to resolve the myriad problems in the Klamath Basin by addressing water conflicts, endangered species habitat, and was connected to dam removal agreements (described in Gosnell and Kelly 2010). In negotiations, the primary ask of the Klamath Tribes was the Mazama, and its reacquisition linked land ownership and economic and social well-being:

This is the Tribes' very first timber-based industry in over 50 years since termination ... when the Klamath Tribes were their most prosperous, it was because of our land and our forest, our ability to create jobs and a future ... with Mazama, we can move in that direction again. (Jeff Mitchell, tribal council member, quoted in Barnard 2008)

The draft KBRA included the provision that the Klamath Tribes receive \$21 million in funds from the U.S. Department of the Interior, supplemented by funds raised by Trust for Public Land, to purchase the Mazama. The Mazama was available for purchase because Fidelity, which had gained control of the Mazama and other former Crown Pacific timberlands, promptly placed the Mazama on the market. Fidelity subsequently agreed to work with the Klamath Tribes on reacquisition, as described by a Fidelity executive:

When we first bought [the land] is when I came across the Klamath Tribes ... it was always a priority of mine to find a way to get them the Mazama Tract. (Fidelity executive, 2008 interview)

The Fidelity executive explained that the land had little real estate value because of its isolation, and little remaining commercial timber value because of historical harvesting practices, and so the Tribes were "the logical buyer" (Fidelity executive, 2008 interview).

The draft KBRA had vocal dissent from many irrigators who felt that they did not have a seat at the table. In an op-ed sent to regional papers, a Supervisor for Siskiyou County in the Klamath Basin in California said that the KBRA was:

Many wolves and a sheep sitting down to decide what's for dinner. It's a trade where special interests bargained away the health, safety and property of those not permitted to participate in the back room secretive process. (Armstrong 2009)

An interesting change in circumstances had occurred. According to the Siskiyou County supervisor, the Tribes had become wolves, and the once-dominant (Euro-American) irrigators had become sheep, relatively powerless and without access to the real decision-making processes. 
A survey commissioned by state Congressmen from Klamath County seemed to indicate that public sentiment mirrored this perception of events. The survey measured Klamath County citizens' attitudes toward the KBRA, and found overwhelming majorities opposed to the agreement. ${ }^{6}$ Of 300 sampled registered voters in the county, 68\% opposed "public purchase of a new reservation for the Klamath tribes" and 73\% opposed the "closed and confidential negotiations in developing" the KBRA (Whitsett 2009: 1).

Despite this level of opposition, the KBRA was signed by the U.S. Secretary of the Interior, the governors of California and Oregon, and the chairmen of all affected tribes:

The days of the best deal you're ever going to get is gone. It's not the best deal for the Tribes, it's not the best deal for the irrigators, it's what everybody thinks they can live with. (Klamath Basin rancher and irrigator, 2009 interview)

The KBRA, and its associated dam removal package, currently await approval and funding from the U.S. Congress.

In the meantime, in 2008 , the Klamath tribes purchased a 44-ha former mill site located within the boundaries of the Mazama. Joe Kirk, the tribal chairman, said: "the [industrial] park will focus on the development of forest-based enterprises that can utilize small diameter trees and other by-products of wildfire hazard reduction treatments and other forest restoration activities" (quoted in Indian Country News 2008). The 2008 Johnson Plan, though created initially for the ponderosa pine-dominated federal lands, was reinterpreted to guide management on the lodgepole pine-dominated Mazama, as it "covers the whole range of habitat types and conditions" (Klamath tribal forester, 2008 interview).

\section{Discussion}

The Mazama would be a toe in the door for tribal land access, and an opportunity to demonstrate management competence. The Klamath Tribes' ability to regain ownership of the Mazama has arisen because of a complex a combination of circumstances, but this case can be extended to other tribal land re-acquisition efforts through several important lessons. First, tribes are negotiating a space within a rapidly-changing rural landscape, wherein power relations, land use, and economic opportunities are being redefined. Second, the clear need for restoration of many formerly-industrial forests indicates an important role for tribal groups with historical and cultural ties to the land. Third, the capacity of tribes may be further reinforced through land ownership and control, contributing to a global trend toward growing tribal rights and sovereignty.

\section{Rural restructuring}

This case demonstrates the impacts of rural restructuring in two ways: the dissolution of formerly industrial forests and their subsequent availability on the market; and the shift from productivist management, focused on timber optimization, toward post-productivist or post-industrial management, which is "concerned with the broader regulation of forest ecosystems and environments" (Milbourne et al. 2008: 617). These shifts also signal a profound change in the power relationships expressed in rural western landscapes - in this case a decline in forest and agricultural commodity production and corresponding decline in the power and relevance of timber and agricultural producers; and a rise in tribal power, particularly regarding access to natural resource management and negotiations surrounding natural resource conflicts. This is in keeping with other tribes that have become active participants in negotiated agreements on their traditional lands (Desbiens 2004; O'Faircheallaigh and Corbett 2005; Waage 2001). The decline in power of timber and agricultural producers has not made these actors less powerful than tribes, but has decreased some of the historical advantage of these groups regarding land use, especially in the global marketplace in which all producers must compete.

This case echoes the findings of Holmes (2010), who described emerging Aboriginal land tenures as part of a shift in northern Australia from productivism toward more multifunctional land uses, including conservation and tourism. Likewise, Indian tenures in the American West are one component of a changing rural landscape wherein consumption and protection values are gaining importance. Holmes (2010) attributed these changes in Australia to global market changes, such as the overcapacity in agricultural systems and globalization. Rural restructuring in the American West has also occurred partly as a result of global market shifts.

But this case also demonstrates the importance of capacity-building for tribes to participate in land purchases, as noted by an employee of the Trust for Public land, who said that "if [tribes] have an already functioning timber and forest program, they are more likely to get more land" (TPL employee, 2009 interview). Capacity within a group includes the ability to solve problems, functional governance, and

\footnotetext{
${ }^{6}$ The Klamath Tribes constitute a small minority of residents in Klamath County. We note that the survey had a number of flaws, including leading questions and unclear methodology.
} 
effective leadership and organizational collaboration (Chaskin 2001). For the Klamath Tribes, capacity was developed internally - both through hiring a member as the tribal forester and through purchasing a mill site - but it was also bolstered by linkages with multiple outside groups. These included the Trust for Public Lands, which offered staff for the Klamath Tribes, visited with federal negotiators, and worked with other non-profits to help the Tribes; the scientists who developed a forest management plan; and through negotiations with irrigators and government staff that were supported by a framework of enabling legislation. The last point supports the claims of Wilkinson (2005) that tribes in the U.S. have successfully drawn on powers formalized through the establishment of reservations and treaties.

\section{Restoration on tribal lands: converging types of knowledge}

The Mazama may demonstrate that western scientific and indigenous ecological views are compatible in forest management. Tribes, as owners, can turn to non-tribal science to inform their management, and some managers and researchers have begun to access indigenous knowledge in a quest to move beyond stark human-nature divides (Pierotti and Wildcat 2000). The Menominee Tribe in Wisconsin, for example, has worked to combine scientific forest management with a cultural land ethic: "The strong conviction of the Menominee people demanded that technical methods of forest management be developed to match their commitment" (Pecore 1992: 15). Both scientific and traditional ecological knowledge are empirical, and may be viewed as complementary: western science emphasizes generalized knowledge, and traditional ecological knowledge offers a "depth of experience in a local context" (Becker and Ghimire 2003: online; see also Kimmerer 2002) and long-term application in particular locations (Berkes et al. 1995; Ramakrishnan 2007).

In commissioning a management plan by western scientists (the Johnson Plan), the Klamath Tribes indicated their commitment to traditional and to scientific ecological knowledge. The Johnson Plan incorporates tribal management goals, as elaborated by the Tribes, with scientific restoration principles. The management vision offered by the Klamath Tribes in the Johnson Plan was scientifically compelling, especially in light of recent moves toward ecosystem management and forest management based on principles of resilience (Grumbine 1994; Puettman et al. 2008). The Plan was grounded in the best available science, with peer reviews from four internationally renowned forest ecologists. Dr. John Gordon, Professor Emeritus of Forestry at Yale, noted that "the plan passes review with flying colors" and commended it for its careful attention to ecological trends, long-term forest conditions, and plans for monitoring and adaptive research (Johnson et al. 2008: 209).

The Klamath Tribes' use of the Johnson Plan in conjunction with traditional ecological knowledge also parallels the experiences of First Nations groups in Canada, where co-management and recognition of Aboriginal land rights have led to some blending of traditional ecological and western scientific management systems (Wyatt 2008). There has been at least superficial recognition of the importance of traditional ecological knowledge, though western scientists and managers can in fact 'cherry pick' components of traditional ecological knowleddge to suit western objectives (Stevenson, 2006). Stevenson points to the possibility of the coexistence of two distinct paradigms that contribute to planning and decision-making, with practioners of traditional ecological knowledge and scientific, state-sanctioned knowledge influencing and informing each other (Stevenson 2006). Wyatt (2008) suggested further that the adoption of traditional ecological knowledge is less important than creating the institutions necessary for meaningful Aboriginal forestry, "based on aboriginal values, systems, and paradigms, and supported by the science and technology of mainstream forestry" (Wyatt 2008: 178).

\section{Reinforcing tribal capacity}

Recognizing the dynamic nature of ecological and social systems, the re-acquisition of the Mazama is not only about historical management, but about current livelihoods and conditions. Therefore, land reacquisition for the Klamath Tribes is not a return to pre-settlement conditions, but a restructuring of social priorities (Cleaves 1997). This combination of modern economic and management practices with historical and place-based identification can be conceived as hybrid natures, incorporating "multiple constructions of nature in order to negotiate with translocal forces while maintaining a modicum of autonomy and cultural cohesion" (Escobar 1999: 13). In other words, current claims to land extend beyond tradition and cultural preservation to employment, livelihood, and political engagement (Rangan and Lane 2001; Stephen 1998). The Klamath Tribes have demonstrated commitment to the restoration of the Mazama, and the interdependence of the forest with their cultural and economic futures. The Tribes therefore have not only moral claims to the Mazama; they may have the greatest capacity for managing it. The Klamath Tribes demonstrated substantial forest management capacity through the Johnson Plan, a more scientifically rigorous forest management plan than those created by industry and overseen by the USFS, and through the proposed building of a new mill.

In addition, the reach of the Klamath Tribes could extend beyond the boundaries of the Mazama because of the 2004 Tribal Forest Protection Act (TFPA), which facilitates tribal-federal partnerships by granting restoration contracts to tribes neighboring national forests. This would give the Tribes some 
management access to their Reservation that became national forest; TFPA contracts are given consideration because of "the cultural, traditional, and historical affiliation of the Indian tribe with the land subject to the proposal" as well as treaty rights and indigenous knowledge (25 USC $3101 \S 2(\mathrm{e})(2))$. The TFPA is evidence of the recognition - in this case by the U.S. government - of the links between tribal capacity and land access.

\section{Limits to capacity}

Though the Tribes and their partners have demonstrated immense capacity, both through leveraging treaty rights in order to regain land, and through the creation of management plans for that land, they are limited by a wide range of circumstances, including economic limitations of the land base, ongoing political conflicts in the Klamath Basin, and internal tribal capacity constraints and potential conflicts. First, the Mazama has extensively degraded landscape conditions, which will likely require both expensive restoration projects and patience. This will complicate the meeting of economic ambitions. Second, the Tribes are still dependent upon the fulfillment of the KBRA, which still requires a number of complicated political negotiations, in order to purchase the Mazama. Third, the human and social capital of the Tribes have been systematically degraded by political actions in the mid $-20^{\text {th }}$ century, such as termination. There may be legitimate questions regarding whether the Tribes have maintained and re-built sufficient capacity to restore the Mazama. Finally, the Tribes are far from homogeneous and internal politics and conflicts could undoubtedly play a role in land management decisions. These conflicts do not need to paralyze decisionmaking, but the traditional ecological knowledge and the interests of tribal members should not be considered to be monolithic.

\section{Conclusion}

Political ecology provides a framework for understanding linkages between diverse social actors, between societies and the landscapes they inhabit, and between local and global influences. In the case of the Klamath Tribes' efforts to reclaim the Mazama, all of these elements are apparent. As the historical and contemporary records clearly demonstrate, the history of the indigenous populations of the Klamath Basin is one of subjugation and loss to dominant Euro-American political and social forces, and central to the loss of autonomy and power was the loss of land tenure rights. The transformation of the Mazama reflects its historical progression from being a source of subsistence and cultural identity, to becoming a source of raw material for export by multinational corporations, and finally to its current position as a locus of negotiation and potential for cultural and economic revitalization for the Tribes. After years of Indian displacement by Euro-American institutions, including the effects of industry, restructuring within the timber industry itself has resulted in opportunities for re-establishing Indian land ownership.

As the case of the Mazama demonstrates, in the American West tribal-non-tribal power relations are shifting, with resulting conflicts between tribes and established agricultural interests. Furthermore, within the broadly-defined competing interests ("tribal" and "irrigator"), disagreements are evident. Future research should examine how social relations as well as forest conditions in the Basin evolve as the land tenure patterns and concomitant land use and economic development opportunities change.

If the Klamath Tribes re-acquire the Mazama, changing power structures and natural resource access in the wake of tribal land re-acquisition will need to be further explored. If, on the other hand, the Tribes fail to re-acquire the Mazama, the reasons behind this failure should be assessed. This article provides a platform for understanding tribal land reacquisition in the midst of remarkable shifts in rural land ownership; future research should explore how this land reacquisition impacts tribes, non-tribal neighbors, and the land.

\section{References}

Albrecht D.E. 2004. Amenities, natural resources, economic restructuring, and socioeconomic outcomes in nonmetropolitan America. Journal of the Community Development Society 35: 36-52.

Armstrong M.H. 2009. The Klamath Basin Restoration Agreement: many wolves and a sheep. 06/16/09 OpEd sent to regional papers.

Barnard J. 2008. Klamath tribes see better future. Associated Press 12/21/08.

Bayona L. 2002. The case against restoring the reservation. Oregon Herald and News 12/21/02. Klamath Falls, Oregon.

Becker C.D. and Ghimire, K. 2003. Synergy between traditional ecological knowledge and conservation science supports forest preservation in Ecuador. Ecology and Society 8(1), 1 [online].

Berke P.R., Ericksen N., Crawford J. and Dixon J. 2002. Planning and indigenous people: human rights and environmental protection in New Zealand. Journal of Planning Education and Research 22(2): 115134. 
Berkes F., Folke C. and Gadgil M., 1995. Traditional ecological knowledge, biodiversity, resilience and sustainability. In: Perrings C.A., Maler, K.G., Folke C., Jansson B.O., and Holling C.S. (eds.) Biodiversity conservation. Dordrecht: Kluwer Academic Publishers. Pp. 281-299.

Blair B. 2010. A legacy of Native lands. Land and People Spring/Summer 2010: 37.

Bliss J.C., Kelly E.C., Abrams J., Bailey C. and Dyer. J. 2010. Disintegration of the US industrial forest estate: dynamics, trajectories, and questions. Small-Scale Forestry 9: 53-66. version

Braun, B., 2002. The intemperate rainforest: nature, culture, and power on Canada's West Coast. Minneapolis, MN: University of Minnesota Press.

Braunworth W.S., Welch T., Hathaway R. 2002. Water allocation in the Klamath Reclamation Project, 2001: an assessment of natural resource, economic, social, and institutional issues with a focus on the Upper Klamath Basin. Corvallis, Oregon: Oregon State University Extension.

Bryant R.L. 1998. Power, knowledge and political ecology in the third world: a review. Progress in Physical Geography 22(1): 79-94.

Castree N. 2004. Differential geographies: place, indigenous rights, and local resources. Political Geography 23(2): 79-94.

Chaskin R.J. 2001. Building community capacity: a definitional framework and case studies from a comprehensive community initiative. Urban Affairs Review 36: 291-323. version

Cleaves H. 1997. Nature, neoliberalism, and sustainable development: between Charybdis and Scylla? Paper presented at the 4th Ecology Meeting on Economy and Ecology, Viseu, Portugal.

Crown Zellerbach. 1970. Mazama Tree Farm ten-year management plan 1970. Lakeview Ranger District, Fremont-Winema National Forest. Lakeview, OR: US Forest Service.

1980. Mazama Tree Farm Ten-Year Management Plan 1980. Lakeview Ranger District, FremontWinema National Forest. Lakeview, OR: US Forest Service.

Dempsey J. 2010. Tracking grizzly bears in British Columbia's environmental politics. Environment and Planning A 42: 1138-1156.

Desbiens C. 2004. Producing North and South: a political geography of hydro development in Quebec. The Canadian Geographer 48(2): 101-118.

Doremus H. and Tarlock A.D. 2008. Water war in the Klamath Basin: macho law, combat biology, and dirty politics. Washington, DC: Island Press.

Escobar A. 1999. After nature: steps to an antiessentialist political ecology. Current Anthropology 40(1): 130.

Getches D.H., Wilkinson, C.F. and Williams, R.L. 2005. Cases and materials on Federal Indian law. St. Paul, MN: Thomson/West.

Gosnell H. and Abrams J. 2011. Amenity migration: diverse conceptualizations of drivers, socioeconomic dimensions, and emerging challenges. Geojournal 76(4): 303-322.

Gosnell H. and Kelly E.C. 2010. Peace on the river? Exploring linkages between the tribal trust responsibility, large dam removal, and socio-ecological restoration in the Klamath Basin, USA. Water Alternatives 3(2): 361-383.

Grumbine R.E. 1994. What is ecosystem management? Conservation Biology 8(1): 27-38.

Harvard Project. 2002. Yakama Nation Land Enterprise Confederated Tribes and bands of the Yakama Nation. The Harvard Project on American Indian Economic Development, John F. Kennedy School of Government, Cambridge, MA. http://www.hks.harvard.edu/hpaied/hn/hn_2002_land.htm.

Harvey D. 2007. Neoliberalism as creative destruction. The Annals of the American Academy of Political and Social Science 610: 22-44.

Hecht P. 2001. Rally demands water for farmers in Oregon's Klamath Basin. The Sacramento Bee 8/22/01.

Herald and News. 2009. Wyden's plan for forests looks like a breakthrough. Klamath Falls Herald and News. Klamath Falls, Oregon. 12/28/2009.

Hibbard M. 2006. Tribal sovereignty, the white problem, and reservation planning. Journal of Planning History 5(2): 87-105.

Hibbard M. and Lane M.B. 2004. By the seat of your pants: indigenous action and state response. Planning Theory and Practice 5(1): 97-102.

Holmes J. 2010. The multifunctional transition in Australia's tropical savannas: the emergence of consumption, protection, and Indigenous values. Geographical Research 48(3): 265-280.

Hood S. 1972. Termination of the Klamath Indian Tribe of Oregon. Ethnohistory 19(4): 379-392.

Indian Country News. 2008. Klamath Tribes acquire the Crater Lake Mill site. Indian Country News 11/08. http://indiancountrynews.net/index.php?option=com_content\&task=view\&id=5118\&Itemid=84 .

Ishiyama N. 2003. Environmental justice and American Indian tribal sovereignty: case study of a land-use conflict in Skull Valley, Utah. Antipode 35(1): 119-139. 
Jaeger W.K. 2002. What actually happened in 2001? A comparison of estimated impacts and reported outcomes of the irrigation curtailment in the Upper Klamath Basin. In Braunworth J. and Welch T. (eds.) Water allocation in the Klamath Reclamation Project, 2001: an assessment of natural resource, economic, social, and institutional issues with a focus on the Upper Klamath Basin. Corvallis, OR: Oregon State University Extension. Pp. 265-283.

Johnson K.N., Franklin J. and Johnson D. 2008. A plan for the Klamath Tribes' management of the Klamath Reservation Forest: prepared for the Klamath Tribes. Chiloquin, Oregon.

Kimmerer R.W. 2002. Weaving traditional ecological knowledge into biological education: a call to action. BioScience 52(5): 432-438.

Klamath Tribes. 2000. Klamath Constitution. Chiloquin, OR: Klamath Tribal Courts, Klamath Tribes. http://www.klamathtribalcourts.com/constitution.pdf. 2012a. Termination. Chiloquin, OR: Klamath Tribes. http://www.klamathtribes.org/information/background/termination.html. 2012b. The long struggle home: the Klamath Tribes; fight to restore their land, people and economic self-sufficiency. Chiloquin, OR: Klamath Tribes. http://www.klamathtribes.org/information/background/home.html.

Marbut R. 2002. Legal aspects of Upper Klamath Basin water allocation. In Braunworth J. and Welch T. (eds.) Water allocation in the Klamath Reclamation Project, 2001: an assessment of natural resource, economic, social, and institutional issues with a focus on the Upper Klamath Basin. Corvallis, OR: Oregon State University Extension. Pp 75-90.

Mather A.S. 2001. Forests of consumption: postproductivism, postmaterialism, and the postindustrial forest. Environment and Planning C 19(2): 249-268.

McCarthy J. 2004. Privatizing conditions of production: trade agreements as neoliberal environmental governance. Geoforum 35: 327-341. 2002. First world political ecology: lessons from the Wise Use movement. Environment and Planning A 34(7): 1281-1302.

McHenry M.G. 2003. The worst of times: a tale of two fishes in the Klamath Basin. Environmental Law 33: 1019-1058.

Memon P.A. and Wilson G.A. 2007. Contesting governance of indigenous forests in New Zealand: the case of the west coast forest accord. Journal of Forest Planning and Management 50(6): 754-764.

Middleton B.R. and Kusel, J. 2007. Northwest Economic Adjustment Initiative assessment: lessons learned for American Indian community and economic development. Economic Development Quarterly 21(2): 165-178.

Milbourne, P., Marsden, T. and Kitchen, L. 2008. Scaling post-industrial forestry: the complex implementation of national forestry regimes in the southern valleys of Wales. Antipode 40(4): 612631.

Morgan T. 1890. $59^{\text {th }}$ Annual Report of the Commissioner of Indian Affairs to the Secretary of the Interior. Washington, DC: U.S. Office of Indian Affairs.

Neuberger R.L. 1955. Letter from Senator Richard L. Neuberger to L.L. Shaw, June 8, 1955. Klamath Falls, Oregon: Lawrence Shaw Collection, Klamath Reservation Dissolution Folder, Oregon Institute of Technology Shaw Library.

- 1959. How Oregon rescued a forest. Harper's Magazine 218(1307): 49-52.

O'Faircheallaigh, C. and Corbett, T. 2005. Indigenous participation in environmental management of mining projects: the role of negotiated agreements. Environmental Politics 17(5): 629-647.

ODF (Oregon Department of Forestry) 2009a. ODF acquisition of the Gilchrist Tract. Salem. OR: Oregon Dept. of Forestry.

2009b. Annual timber harvest reports. Salem, OR: Oregon Dept. of Forestry. http://www.oregon.gov/ODF/STATE_FORESTS/FRP/Charts.shtml\#Downloads.

Oliver C.D., Irwin L.L., and Knapp W.H. 1994. Eastside forest management practices: historical overview, extent of their applications, and their effects on sustainability of ecosystems. Portland, OR.: PNWGTR-324, US Dept. of Agriculture, Forest Service, Pacific Northwest Research Station.

Oregon Employment Department, 2009. Covered employment and wages Salem, Oregon: Oregon Labor Market Information System. http://www.qualityinfo.org/olmisj/CEP? $\mathrm{x}=1 \& \mathrm{y}=1$.

Pecore M. 1992. Menominee sustained-yield management: a successful land ethic in practice. Journal of Forestry 90(7): 12-16.

Pierotti R. and Wildcat D. 2000. Traditional ecological knowledge: the third alternative. Ecological Applications 10(5): 1333-1340.

Prudham S. 2005. Knock on wood: nature as commodity in Douglas-Fir country. New York: Routledge. 
Puettman K.J. Messier C.C. and Coates K.D. 2008. A critique of silviculture: managing for complexity. Washington, DC: Island Press.

Ramakrishnan P.S. 2007. Traditional forest knowledge and sustainable forestry: A north-east India perspective. Forest Ecology and Management 249: 91-99.

Rangan, H. and Lane M.B. 2001. Indigenous peoples and forest management: comparative analysis of institutional approaches in Australia and India. Society and Natural Resources 14: 145-160.

Rasmussen K., Hibbard, M. and Lynn K. 2007. Wildland fire management as conservation-based development: an opportunity for reservation communities? Society and Natural Resources 20: 497510.

Robbins P. 2004. Political Ecology. Malden, MA: Blackwell.

Ross T. 2009. Indian tribes buy back thousands of acres of land. Associated Press Dec. 28, 2009.

Semmens G.N. 1976. Crown Zellerbach Corporation - Klamath Indian Lands points for review prior to preparation of new management plan. Available at Fremont-Winema Lakeview National Forest Ranger District, Lakeview, OR.

Stephen, L. 1998. Between NAFTA and Zapata: responses to restructuring the commons in Chiapas and Oaxaca, Mexico. In: Goldman, M. (ed.) Privatizing nature: political struggles for the global commons. New Brunswick, NJ: Rutgers University Press. Pp. 76-101.

Stern T. 1961. Livelihood and tribal government on the Klamath Indian Reservation. Human Organization 20(4): 172-180.

1965. Klamath Tribe: a people and their Reservation. Seattle, WA: University of Washington Press.

Stevenson M.G. 2006. The possibility of difference: rethinking co-management. Human Organization 65(2): 167-180.

Takeda L and Ropke I. 2010. Power and contestation in collaborative ecosystem-based management: the case of Haida Gwaii. Ecological Economics 70: 178-188.

Tonsfeldt, W. 1980. Historical resources survey for rural areas in Klamath County, Oregon. Bend, OR: Ward Tonsfeldt Consulting.

Trulove W.T. and Bunting, D. 1971. The economic impact of federal Indian policy: incentives and response of the Klamath Indians. Cheney, WA: Eastern Washington State College.

USFS 1959. Minimum requirements for sustained-yield management. In Originally entitled sample sustained-yield plan. Lakeview, Oregon: Lakeview Ranger District, Fremont-Winema National Forest, US Forest Service.

Waage S.A. 2001. (Re)claiming space and place through collaborative planning in rural Oregon. Political Geography 20: 839-857.

Walker P. and Fortmann, L. 2003. Whose landscape? A political ecology of the 'exurban' Sierra. Cultural Geographies 10: 469-491.

Whitsett D. 2009. Klamath River Dam survey. Klamath Falls, Oregon: Target Research Company. http://www.klamathbasincrisis.org/whitsett/survey/kbrapoll051409.htm.

Wilcox E.R. 1956. Forestry implications of the Klamath Termination Law (P.L. 587): Bureau of Indian Affairs. Available at the Fremont-Winema Lakeview Ranger District.

Wilkins D.E. 1987. American Indians, time, and the law: native societies in a modern constitutional democracy. New Haven: Yale University Press.

Wilkinson C.F. 1992. Crossing the next meridian. Washington, DC: Island Press. 2005. Blood struggle: the rise of modern Indian nations. New York: W.W. Norton.

Wilson G.A. 2007. Multifunctional agriculture: a transition theory perspective. Oxford: CABI.

Winkler R., Field D.R., Luloff, A.E., Krannich R.S. and Williams T. 2007. Social landscapes of the InterMountain West: a comparison of 'Old West' and 'New West' communities. Rural Sociology 72(3): 478-501.

Wright A.H. 1956. Data on termination of federal supervision over the Klamath Indian Reservation. Salem, OR: Oregon State Dept. of Education. Available at the Special Collections, Oregon State University.

Wyatt S. 2008. First Nations, forest lands, and "aboriginal forestry" in Canada: from exclusion to comanagment and beyond. Canadian Journal of Forest Resources 38: 171-180.

Youngblood A., Max T. and Coe K. 2004. Stand structure in eastside old-growth ponderosa pine forests of Oregon and northern California. Forest Ecology and Management 199: 191-217.

Zaferatos N.C. 2004. Tribal nations, local governments, and regional pluralism in Washington State. Journal of the American Planning Association 70(1): 81-96.

Zaferatos N.C. 2006. Environmental justice in Indian Country: dumpsite remediation on the Swinomish Indian Reservation. Environmental Management 38(6): 896-909. 


\begin{abstract}
After years of policies that undermined tribal sovereignty and land ownership, tribal access to traditional lands has expanded in the U.S., with growing opportunities for tribal land reacquisition. This is occurring within the context of changing rural land use, policies, and tenures, as timber and ranch land owners have divested ownership, resulting in greater land availability. This case study explores, through a political ecology lens, trends connecting rising tribal capacity and power with access to traditional lands, and the connections between politics, economics, race, power, and ecological change. This case provides lessons for indigenous land re-acquisition elsewhere, as indigenous groups globally gain access to political decisionmaking processes and seek to reacquire or rehabilitate their traditional homelands. We explore these trends through the case of the Klamath Tribes in south central Oregon, where the recent breakup of formerly industrial timberland has afforded the Tribes the opportunity to purchase the Mazama Tree Farm, a 36,000 ha part of the former Klamath Reservation. Though the Mazama has not (at the time of publication) been purchased by the Klamath Tribes, they have poised themselves to do so through a series of mechanisms that are driven by increasing tribal capacity, including the capacity to manage forests and to conduct successful negotiations over land and water use.
\end{abstract}

Key words: Tribal capacity, forest restoration, American West, rural restructuring, industrial forest use

\title{
Résumé
}

Aux États-Unis, après des années de politiques qui ont sapé la souveraineté tribale et leur propriété foncière, l'accès aux terres tribales a étendu, avec des opportunités de croissance pour la réacquisition des terres. La reprise de terres qui se produit dans le contexte d' évolution de l'utilisation des terres rurales, les politiques et le foncier. Les propriétaires de ranches et de forêts ont cédé la propriété, résultant en une plus grande disponibilité des terres. Cette étude de cas explore, à travers une lentille de l'écologie politique, les tendances qui se connectent une croissance de la capacité tribale et le pouvoir d'accéder à leurs terres traditionnelles. Il montre également les liens entre la politique, l'économie, la race, de l'énergie et du changement écologique. Les groupes autochtones ont accès à des processus de prise de décisions politiques et ils cherchent à racheter ou à réhabiliter leurs terres traditionnelles. L' article propose quelques leçons pour la ré-acquisition de terres indigènes. Nous explorons ces tendances à travers le cas des tribus Klamath dans le centre-sud de l'Oregon, où la foresterie industrielle a récemment arrêté et la terre est mis en vente. Les tribus ont la possibilité d'acheter le Mazama Tree Farm, une étendue de 36,000 hectares de l'ancienne Réserve de Klamath. Bien que le Mazama n'a pas (au moment de la publication) été acheté par les tribus Klamath, ils sont prêts à acheter à travers une série de mécanismes qui sont entraînés en augmentant la capacité tribal, y compris la capacité à gérer les forêts et à mener des négociations fructueuses sur la terre et l'utilisation de l'eau.

Mots clés: capacité tribal, la restauration des forêts, l'Ouest américain, la restructuration rurale, l'exploitation forestière industrielle

\section{Resumen}

Después de años de políticas que han limitado la soberanía tribal y la propiedad de la tierra, el acceso tribal a tierras tradicionales se ha expandido en los Estados Unidos, con crecientes oportunidades para la recuperación de territorio tribal. Esto se está dando dentro de un contexto de cambios en el uso de la tierra, políticas y tenencias, en medida que los propietarios de ranchos y de bosques han vendido sus propiedades. Este estudio de caso explora a través del lente de la ecología política, las tendencias que conectan el incremento en el poder de las tribus con el control sobre tierras tradicionales, y las conexiones entre política, economía, raza, poder y cambio ecológico. Provee elementos para mejor entender otros casos de recuperación de tierras, en medida que estos grupos a nivel global ganan acceso a los procesos políticos y buscan adquirir tierras. Exploramos esta tendencia a través del caso de tribus de Klamath ubicados en el surcentro del estado de Oregon, en los Estados Unidos, donde el reciente desmantelamiento de la industria maderera le ha dado a las tribus la oportunidad de comprar la Granja de Arboles Mazama, que consiste en 36,000 hectáreas expropiadas de la Reservación Klamath. A pesar de que la Mazama no ha sido comprada por los tribus Klamath (al momento de publicación de este articulo), se ha propuesta hacerlo a través de una serie de mecanismos impulsados por incrementos en la capacidad del tribu, incluye 3ndo la capacidad de manejar bosques y conducir negociaciones sobre tierras y agua de manera exitosa.

Palabras claves: Capacidad tribal, reforestación, Oeste de los Estados Unidos, reestructuración rural, industria forestal 